\title{
ON THE FROST RESISTANCE OF RED CLOVER WITH SPECIAL ATTENTION TO SEED PRODUCTION
}

\author{
Arvi Valmari and Irja Valmari \\ Agricultural Research Centre, Frost Research Station, Pelsonsuo
}

Received December 20, 1965

Grasslands play a part of decisive importance in plant production in the frosty regions of Finland. Red clover has long been considered to be the key species with respect to self-supporting cattle feeding, and it should therefore occur as a part also in the vegetation carried on in cultivated peat areas and in frosty regions. It is true that clover may not be totally indispensable any more, but the desired aim is thought to be more easily attained with the aid of clover.

One of the greatest drawbacks in the way of increased cultivation of clover has been the high price of its seed and the scanty domestic seed production. However, red clover seed farming is just now being taken up in new regions. For instance, in the Oulu - Kajaani area (about $64-65$ degrees N. lat.) seed crop yields of 200 $240 \mathrm{~kg}$ per hectare have been obtained, which is normal as compared to the national average (5, cp. also 3). Clover seed farming is thus about to spread into frosty regions.

The leaves of clover are easily marked by frost. A number of instances have gained publicity in which a clover field intended to bear seed has been cut for fodder owing to frost damage. On the other hand, it is not definitely borne out by statistics of frost years that frost would have affected the quality of the seed. Obviously, therefore, the question calls for closer investigation. It will be studied in the present work on the basis of the data of the investigation that are now available at the Frost Research Station.

The experimental methods have been improved appreciably during the work and the investigation has been partially of orientative character. However, as the results seem to be fairly clear, the publishing of them seems justified. As the primary data are too extensive to be printed in detail, they are published in stencil copies (11).

It should be noted with reference to the authors that A. Valmari has lead the study and written the final paper and I. Valmari has done the field and laboratory work and as the result of common consultations written the first sketch of the paper. 


\section{Experimental conditions}

This work has been carried out at the Frost Research Station at Pelsonsuo $\left(64^{\circ} 31^{\prime}\right.$ N.lat., $26^{\circ} 27^{\prime}$ E. long., $115 \mathrm{~m}$ above sea level). The soil type of the experimental field is mesotrophic peat, with fine sand added at $300 \mathrm{~m}^{3}$ per hectare and ground limestone at $3-8$ tons per hectare as soil improving agents. In these conditions, lime is the factor exerting the most distinct effect on the thriving of red clover, however, disappearance of clover in the winter also occurs for several other reasons than the lack of lime. No experiments expressly devised to clarify the quantity of the seed yield have been carried out at the Research Station, but on the strength of visual assessment the seed yield might attain, on small areas at least, the level normal in Finnish conditions where the overwintering of clover is normal. Pollination is performed by various species of bumblebees (Bombus), whose thriving in the area in question is probably aided by the abundant occurrence of willow (Salix) and rosebay (Chamaenerion angustifolium) along the ditches and the roadsides.

Samples were taken in the years 1958-1960 partly from field experiments and partly from farm fields. When no special mention is made of the variety, the material was obtained from a clover-timothy stand established in 1957 with domestic commercial seed produced in S. W.-Finland.

Table 1. Temperature and rainfall at Pelsonsuo in 1958-1960.

Taulukko 1. Lämpötila ja sademäärä Pelsolla vuosina 1958-1960.

\begin{tabular}{|c|c|c|c|c|c|c|c|c|c|c|}
\hline \multirow[t]{2}{*}{$\begin{array}{l}\text { Year } \\
\text { Vuosi }\end{array}$} & \multicolumn{5}{|c|}{$\begin{array}{c}\text { Mean temperature, }{ }^{\circ} \mathrm{C} \\
\text { Keskilämpötila }{ }^{\circ} \mathrm{C}\end{array}$} & \multicolumn{5}{|c|}{$\begin{array}{l}\text { Rainfall, mm. } \\
\text { Sademäärä } m m\end{array}$} \\
\hline & V & VI & VII & VIII & IX & V & VI & VII & VIII & IX \\
\hline 1958 & 6.1 & 12.6 & 13.7 & 13.7 & 7.3 & 53.5 & 30.6 & 105.2 & 32.6 & 12.4 \\
\hline 1959 & 7.7 & 13.9 & 15.8 & 14.0 & 5.9 & 33.2 & 20.3 & 24.3 & 119.7 & 28.6 \\
\hline 1960 & 10.6 & 14.7 & 18.4 & 14.3 & 7.9 & 22.5 & 79.7 & 49.4 & 90.4 & 17.9 \\
\hline $\begin{array}{c}\text { Mean }- \text { Kes } \\
1921-1950 \\
1931-1960\end{array}$ & $\begin{array}{l}7.0 \\
6.9\end{array}$ & $\begin{array}{l}12.6 \\
13.0\end{array}$ & $\begin{array}{l}16.3 \\
16.1\end{array}$ & $\begin{array}{l}13.7 \\
14.3\end{array}$ & $\begin{array}{l}8.0 \\
8.7\end{array}$ & $\begin{array}{l}39 \\
32\end{array}$ & $\begin{array}{l}61 \\
65\end{array}$ & $\begin{array}{l}73 \\
68\end{array}$ & $\begin{array}{l}64 \\
71\end{array}$ & $\begin{array}{l}57 \\
53\end{array}$ \\
\hline
\end{tabular}

Table 1 contains data describing the conditions of temperature and rainfall in the summers of 1958-1960. This period includes the frost year 1959, when the crop yields for barley and oats were among the lowest and for the potato crop the very lowest, recorded at Pelsonsuo during the period 1942-1965, for which years statistics relating to equivalent conditions are available for the crop yields at the farm of Pelso Reserve Penitentiary. The minimum temperatures of individual frost nights and a number of temperature curves will be given later.

The Pelso region is level and represents comparatively frost-ridden cultivated fields. It is an area in which the cultivation of spring cereals (of barley and particularly of oats) as well as of potatoes has to be considered unreliable but is generally 
practised all the same. The material of the present investigation was principally derived from a clover stand where the development of seed has been delayed by the circumstance that the first crop was harvested for silage in the latter part of June, a practice that is not recommended in connection with seed cultivation in such northerly conditions. The estimate can therefore be made that in the region of which Pelso is representative, fields in cultivation for clover seed will rarely be subjected in autumn to frost of greater severity than in the present test, perhaps so rarely indeed that a risk of that magnitude would be taken without hesitation in actual farming. Clover seed fields are normally cut in the region in question during the first days of September (7). The bulk of the material concerned which has been harvested at a later date.

\section{Methods}

Fi e l d o b s e r v a t i o n s. The principal specimens considered in the present study were taken immediately from the field, where they had been exposed to natural frost, and were partly left to stand until the onset of winter frost. The $\mathrm{fros} t$ in jury observations have been made in the field by visually assessing the percentage of frozen plant parts. The lowest temperatures in the air were measured with unshielded minimum thermometers (Fuess) placed at the height of the top of the vegetation. Furthermore, thermograph curves will be shown, recorded by a Fuess thermograph at $2 \mathrm{~m}$ height in an instrument screen of the type used at meteorological stations. The stage of development of the plants has been expressed by their height and by the most advanced inflorescence encountered, as follows: about to bud; budding; flowering; and thenceforth by the degree of ripening according to the colour of the corolla: half brown (i.e., $50-70 \%$ of the flowers having a corolla turned brown); brown (corolla brown in more than $70 \%$ ). The lastmentioned category was divided in to two parts in 1960: light brown; and dark brown. The classification according to the brown colour has even been used elswhere both in practical instruction and in scientific work $(4,9)$. Threads of various colour were tied on individual heads to mark their stage of develompent so that their later behaviour could be followed.

$\mathrm{L}$ a boratory f rost t reat ment. In 1958, specimens were subjected to treatment in a refrigerated cabinet of $76 \mathrm{~cm}$ by $138 \mathrm{~cm}$ floor space and $115 \mathrm{~cm}$ height, built at the Research Station. The refrigerating machinery, placed in the ceiling of the cabinet, maintains a constant temperature within $\pm 0.5^{\circ} \mathrm{C}$ except when there are many large plants in the cabinet. There is no artificial ventilation in the cabinet. More details are given in the reference 11.

A n a lysis of flower heads. The heads were individually threshed by hand and the number of seeds in each was counted. For the 1000 -seed-weight and germination percentage determinations, the seeds from several heads belonging to one and the same test group had to be combined.

Determination of germination ability was performed by a simple procedure, which is also suitable for use on farms. The seeds were kept at constant temperature (about $16-18^{\circ} \mathrm{C}$ ) for ten days on a seed testing tray of tile, 
between two pieces of blotting paper, which were kept wet by means of strips of fabric, their ends dipping into a water container. The numbers of germinated, hard and dead seeds were then determined. The average number of seeds in each of the 173 germination tests was 67 , the most usual being 100 . As is usually the case, the germination data include germinated seeds with healthy sprouts, and hard seeds. The injured sprouts are counted as dead ones.

Official germination determinations are made at an alternating temperature during seven days. According to information kindly supplied by Professor A. Hilli, the alternation of the temperature has not been found to exert any noteworthy influence on the germination results. In a control test the results recorded in four determinations made by the State Seed Testing Station fell between those results representing our determinations, approximately consistent with the weight of the seeds.

As the percentage of hard seeds was generally high in this material (apparently because the threshing was done by hand) some control tests were made. When hard seeds were treated with carborundum to scratch the hull, the treated seeds germinated 99 per cent ( 1 per cent apparently got broken in the treatment). When several new germination tests were made with the hard seed (518 seeds altogether) only 2.5 per cent germinated but not a single seed died.

Frost resistance of the vegetative parts of the clover plant

\section{Experiments in the cold cabinet}

A number of experiments were carried out in 1958, in which clover plants at different stages of development were subjected to experimental frost conditions. More and less rigorous treatments were applied in order to obtain an idea of the degree and duration of frost still tolerated by the vegetative parts of the plants. The youngest plants in this series were $8 \mathrm{~cm}$ high, without buds, the oldest ones $55 \mathrm{~cm}$ high, with half-brown heads.

The material is not extensive enough to reveal such differences as may exist between the specimens representing different stages of development or hardening. These do not appear to be great. In the following consideration concerning the significance of temperature and of the duration of cold treatment, therefore we shall pay no attention to the stage of development and treat the entire material as one series.

Two hours' treatment at $-3^{\circ} \mathrm{C}$ caused slight frost injury of the aerial parts. When the temperature was two hours at -5 to $-10^{\circ} \mathrm{C}$ (with several additional hours below zero), the aerial parts were virtually completely destroyed, but the root system did not die and the plants developed new shoots. The temperature limit at which the frost injury strongly increases with further lowering of the temperature and passes the value of $50 \%$, seems to have been about $-4^{\circ} \mathrm{C}$ in the present material for a treatment period of two hours.

The circumstance that some of the plants survived even the eight-hour treatment at $-3^{\circ} \mathrm{C}$ with comparatively little damage is in support of the observation 
that frost injury occurres at a slightly lower temperature, perhaps just about $-4^{\circ} \mathrm{C}$. In the eight-hour treatments positive death of the plants occurred, beginning with $-5^{\circ} \mathrm{C}$. In 13 hours at $-5^{\circ} \mathrm{C}$ all plants died. The cooling of the soil takes place at a higher rate in the cold cabinet than in the field, and obviously the subterranean parts of the plants already may have been so badly damaged in the treatment at $-5^{\circ} \mathrm{C}$ that the plants succumbed.

\section{Conditions in the field}

In nature, conditions during a frost night are different from those achieved in the cold cabinet. In the field, heat supplied from within the soil and the protection furnished by the vegetation itself may maintain a higher temperature in the lower part of a fairly tall and luxuriant plant cover than at its top level, from where heat can escape by radiation and by convection without hindrance. It is true, however, that particularly in a low and sparse plant cover the lowest temperature may prevail at its base level. Soil under an existing plant cover will not freeze to a depth greater than a few centimetres at most during the frosts that occur in the course of the growing period. Some details are given in the reference 11.

From the experiments in the cold cabinet the conclusion emerged that penetration of a low temperature (though not lower than $-5^{\circ} \mathrm{C}$ ) may cause the final death of an unhardened individual clover plant. No observations are made in this connection which could answer the question at which temperature the (hardened) plants die in field conditions. There is evidence that temperatures below $-10^{\circ} \mathrm{C}$ occur at about $5 \mathrm{~cm}$ depth in the soil. On the other hand, in a field test where snow was rolled in the autumn not only all red clover but even most of the timothy grass died in winter. Low soil temperature could be one of the important reasons for poor overwintering of red clover in Finland in regions where the snow cover is thin as compared with a corresponding minimum air temperature in winter (cf. 2, 12).
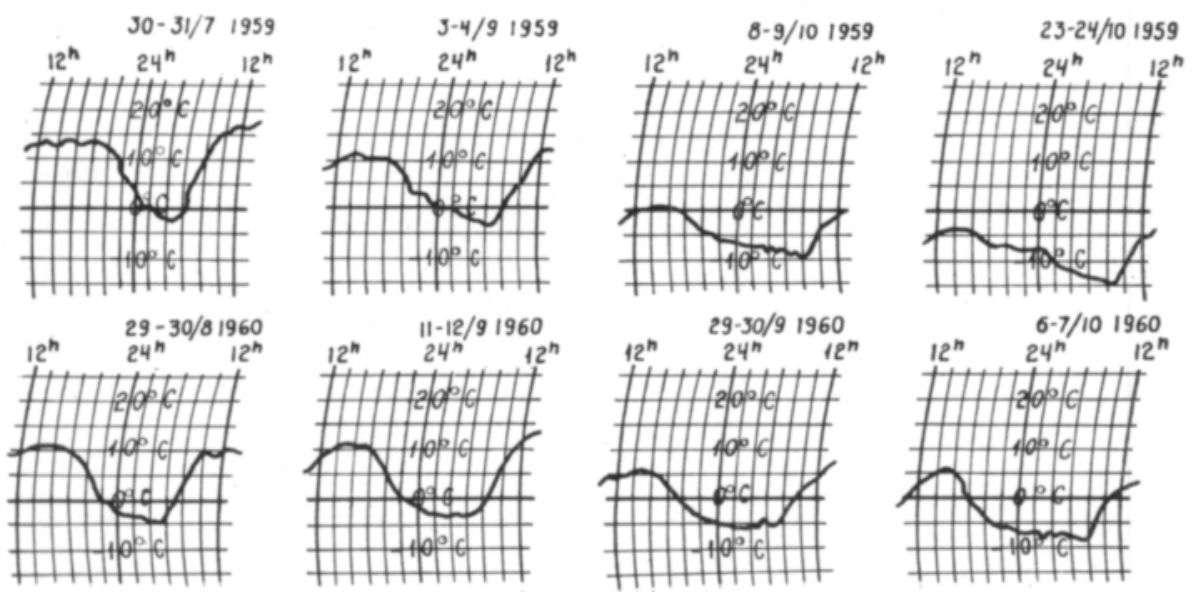

Fig. 1. Thermograph records, showing the temperatures during some frost nights in 1959 and 1960. Recorded in a meteorological screen at $2 \mathrm{~m}$ height above soil surface.

Kuva 1. Termografikäyriä vuosien 1959 ja 1960 hallaöiltä. Mitattu säähavaintokojussa 2 m: $n$ korkeudessa. 


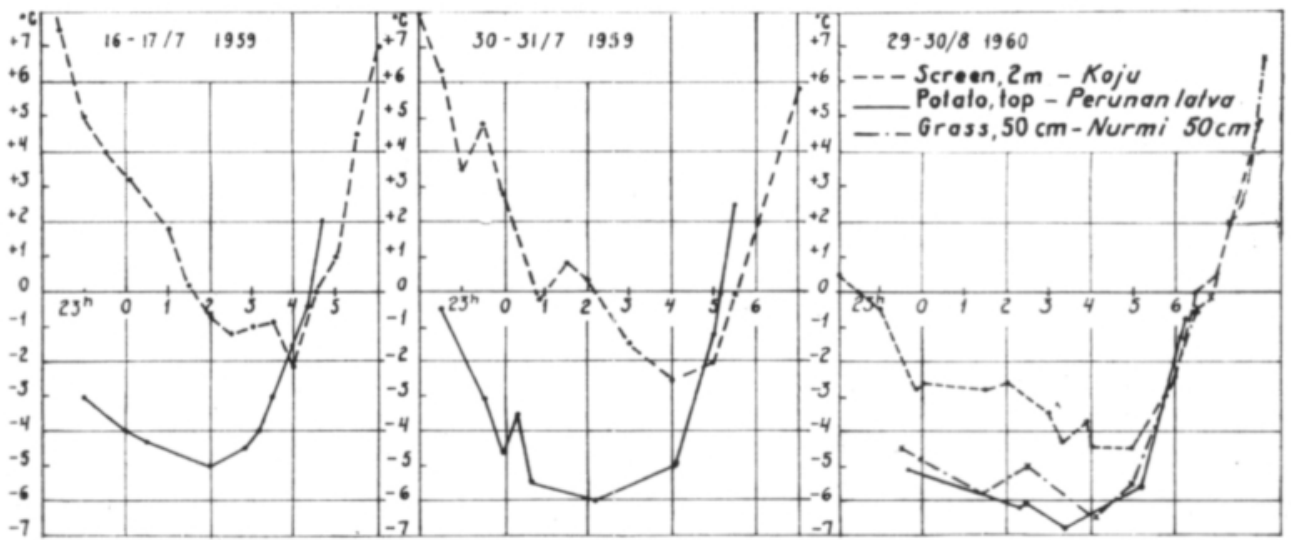

Fig. 2. The course of temperature in the meteorological screen and at plant top height during some frost nights.

Kuva 2. Lämpötilan kulku kojussa ja kasvuston latvassa eväinä hallaöinä.

Fig. 1 shows the temperature curves recorded by the thermograph in a meteorological screen at a height of $2 \mathrm{~m}$ during the most important frost nights to be considered here. The dry summer of 1959 was characterized by a slow and fairly linear decrease of temperature in the screen down to the minimum, followed by a steep ascent. However, the decrease of temperature at the top height of the vegetation is usually more abrupt than in the screen, and the temperature therefore remains close to its minimum longer than is indicated by the thermograph records (cf. Fig. 2).

\section{Observations concerning frost injury to clover in the field}

According to observations made at the Frost Research Station, the consecutive frost nights that occurred at the end of June, 1959 (29. VI: $-4.8^{\circ} \mathrm{C}$, and 30 . VI: $-4.0^{\circ} \mathrm{C}$ at top level of the grass), which caused almost complete destruction of the aerial parts of potatoes and also great damage to the spring cereals, injured only about $0-3 \%$ of the clover leaves. On 17 . VII a temperature of $-5.0^{\circ} \mathrm{C}$ was measured, and the temperature stayed about three hours below $-4^{\circ} \mathrm{C}$, but no considerable damage occurred. On 31 . VII, the minimum was $-6.0^{\circ} \mathrm{C}$ and the temperature was between -5 and $-6^{\circ} \mathrm{C}$ for more than five hours, but the injury amounted only to $0-5 \%$ in the leaves of the clover, which had a height of about $25 \mathrm{~cm}$. In August and in the first half of September, several nights with frost between -4 and $-6^{\circ} \mathrm{C}$ occurred, but the damage was still negligible. Considerable injury was not recorded until the frost nights of late September and early October (most severe among them: $20 . \mathrm{IX},-9.0^{\circ} \mathrm{C} ; 29 . \mathrm{IX},-8.1^{\circ} \mathrm{C} ; 2 . \mathrm{X},-9.1^{\circ} \mathrm{C}$; and $3 . \mathrm{X}$, $-10.0^{\circ} \mathrm{C}$ ). Observations made on $5 . \mathrm{X}$ show the tops of the plants to be damaged by frost over a length of about $10-20 \mathrm{~cm}$, while even then a basal part, $20-25 \mathrm{~cm}$ in length, was intact. In 1959 the hardening effected by the numerous, gradually worsening frost nights may have influenced the results. But in 1960 no exceptional 
hardening may have taken place, since the first significant occurrence of frost in the summer was on 30 . VIII, when the red clover was in the ripening stage (the samples of its heads will be discussed later). The minimum temperature was $-6.8^{\circ} \mathrm{C}$ and the temperature stayed below $-5^{\circ} \mathrm{C}$ about six hours. Now, too, the frost injury, at the most, amounted to a few per cent of the leaves. However, the heads in the flowering or budding stage and those about to bud obviously did not develop subsequently, and on $7 . \mathrm{X}$ the plants constituting the weakest part of the vegetation had snapped off or fallen down, so that the increasing frosts (however, $-12.7^{\circ} \mathrm{C}$ at the most) had put an end to the growth.

In a clover experiment in the same summer (1960), however, the sowing of which had been done on 17 . VI, the luxuriant shoots of about $15 \mathrm{~cm}$ length fared considerably worse. The injury noted on 30 . VIII after a frost of $-6.8^{\circ} \mathrm{C}$ was comparable to that suffered by the clover stand of the second year in 1959 at $-10^{\circ} \mathrm{C}$. The injury of different varieties was (per cent of leaves):

$\begin{array}{lll}\text { Tammisto (Diploid red clover) } & 69 \\ \text { Haapaniemi ( } & 62 \\ \text { Tepa (Tetraploid red clover) } & 78 \\ \text { Ulva ( } & 72 \\ \text { Iso } & \text { (Tetraploid Alsike clover) } & 41\end{array}$

The most essential facts emerging from these observations are: that Finnish tetraploid Alsike clover was clearly more resistant than the diploid red clovers, that the teraploid red clovers were only slightly more susceptible than the diploid red clovers, and that the northerly local strain Haapaniemi of diploid red clover was not quite distinctly superior to the standard variety Tammisto in resistance. The differences that occurred cannot be considered decisive in regard to the value in the cultivation of these varieties.

\section{The influence of frost on the clover head and seed}

From the data of the cold cabinet experiments of 1958 the heads were collected and analyzed which remained on the surviving stalks or grew after the cold treatment. In 1958, specimens of heads were harvested on $5 . \mathrm{X}$ in the clover strain test, after several frosts with temperatures between -7 and $-10^{\circ} \mathrm{C}$ and numerous less severe frosts. In the years 1959 (frost year) and 1960 (good year), head specimens were taken from the test field in great numbers, part of them previously marked at different stages of development for later identification. An attempt was made to take the samples so that they would represent heads not subjected to frost, heads that had suffered from light frosts, and finally heads which had gone through severe frost nights (with about $-24.4^{\circ} \mathrm{C}$ ). Altogether 356 heads were analyzed in 1959 and 97 heads in 1960. The test fields from which the head samples were taken had been cut for AIV silage in June (on 30. VI 1959 and 14. VI 1960, respectively).

Fig. 3 shows the results of all samples from which both the 1000 seed weight and the germination are determined in connection with the present work. The correlation between these properties is evident. Moreover, the figure serves to give a picture of the total scattering which will be analyzed at greater length below. 


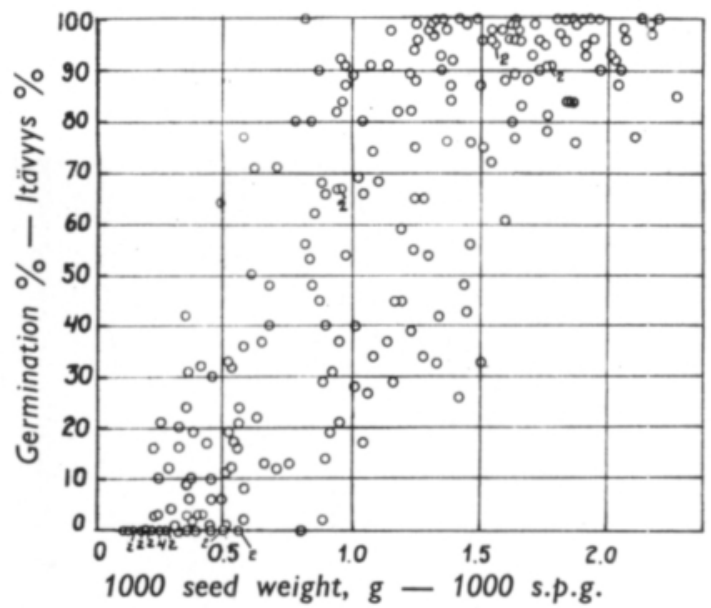

Fig. 3. Relationship of 1000 seed weight and germination ability of red clover seeds.

All the samples analyzed in the present investigation.

Kuva 3. Puna-apilan 1000 siemenen painon ja itävyyden suhde. Kaikki tämän tutkimuksen analysoidut näytteet.

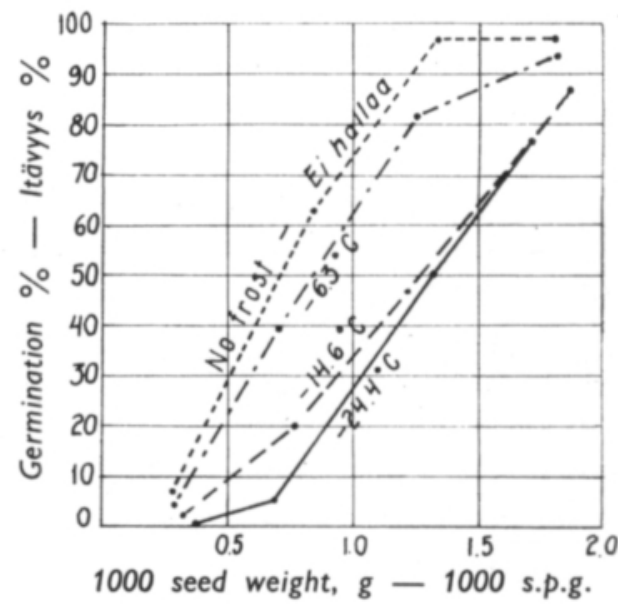

Fig. 4. The effect of frosts of different degrees on the germination ability of red clover seed, based on the combined data of 1959 and 1960 . The two lower curves also contain the additional effect of the fall and early winter weather.

Kuva 4. Eriasteisten hallojen vaikutus punaapilan siemenen itävyyteen vuosien 1959-1960 yhdistetyn aineiston perusteella. Kahteen alimpaan käyrään sisältyy myös syksyn ja alkutalven säiden muu vaikutus.

\section{The effect of frost on the appearance of the head and seed}

No marked change has been observed in the appearance of fully matured heads under the effect of frost; perhaps they become slightly darker. Unripe heads frequently turn brown before their time as a result of exposure to frost. Sometimes the stalk is broken so that the heads hang down.

In the appearance of the seed hardly any changes caused by frost were observed if the 1000 seed weight was at least $1.3 \mathrm{~g}$. Seed smaller than this may be rendered dull and dirty grey-brown or strong dirty green. Moreover, it is flat and wrinkled. The very smallest frost-injured seeds (with less than $0.5 \mathrm{~g} 1000$ seed weight) are dark brown or black (darker and more dingy in colour than healthy seeds), exceedingly flat or of indefinite shape, and very much wrinkled. Besides frost, rain also may turn the seed brown (10).

\section{The effect of frost on germination percentage}

A. The effect of seed size in the absence of frost

A series in which no frost injury can have occurred has been presented in Fig. 4 (topmost curve) to serve as reference. It was derived from the same field as the principal material concerned in this investigation. In Fig. 5 part (a), moreover, the 

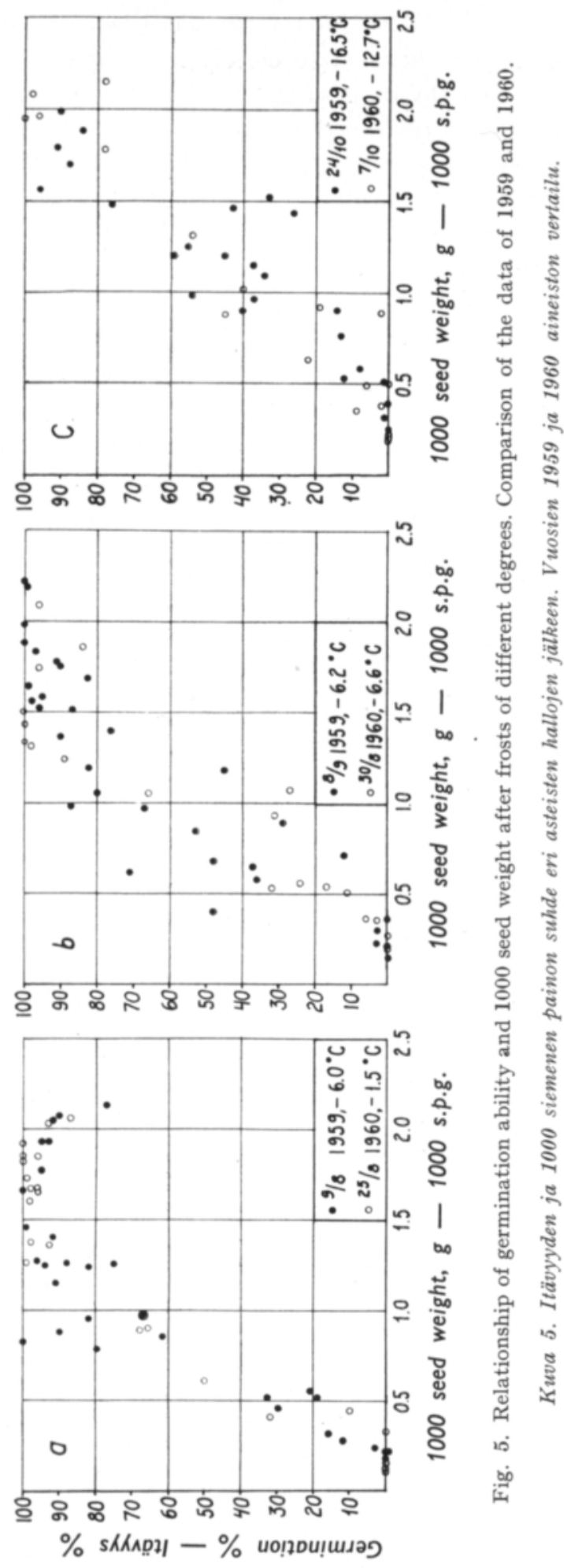
material subjected to slight frost in 1959 (no temperatures below $-6^{\circ} \mathrm{C}$ ) is displayed, which approximated the first-mentioned so closely regarding germinative ability that our study can be made on the basis of the combined, more extensive series.

The seeds of less than $0.2 \mathrm{~g} 1000$ seed weight do not germinate at all. The germination percentage then increases fairly linearly with increasing 1000 -seed-weight from $0.2 \mathrm{~g}$ upwards, so that $50 \%$ germination is reached at about $0.7 \mathrm{~g}$, and 90 $95 \%$ at about $1.3 \mathrm{~g} 1000$ seed weight. A gentle peak is found in the range of 1.5 $1.8 \mathrm{~g}$. The material is thus seen to be well representative of Finnish diploid red clover, for which the 1000 seed weight of $1.5-2.0 \mathrm{~g}$ is stated. Seeds having the 1000 seed weight of $0.8 \mathrm{~g}$ may already exceed the germination limit specified for Finnish commercial seed $(60-70 \%)$. Above $1.8 \mathrm{~g}$ the germination begins to decrease distinctly, obviously for the reason that the largest (oldest) seeds have been subjected to the stress caused by weather conditions too long, even though the crops were collected between 9 . VIII and 25. VIII, that is, before normal harvesting time (which is the beginning of September). August was in fact very rainy in 1959, and the rainfall in the same month in 1960 was also higher than normal (cf. Table 1). On the other hand no defects due to drying in field after cutting can be present in this material because the samples are dried indoors.

The effect of seed size on germination percentage is a factor that must be taken into account in studying of this kind and it will therefore appear in several of the subsequent considerations. Reference can moreover be made in this connection to Fig. 5, which shows the corresponding materials of 1959 and of 1960 to be closely similar; this serves to indicate that the ratio of volume weight and germination is constant from year to year in the present material at least. The arrangements made in connection with the cold cabinet experiments, including the cold treatment itself, did not affect this ratio either (Fig. 6).

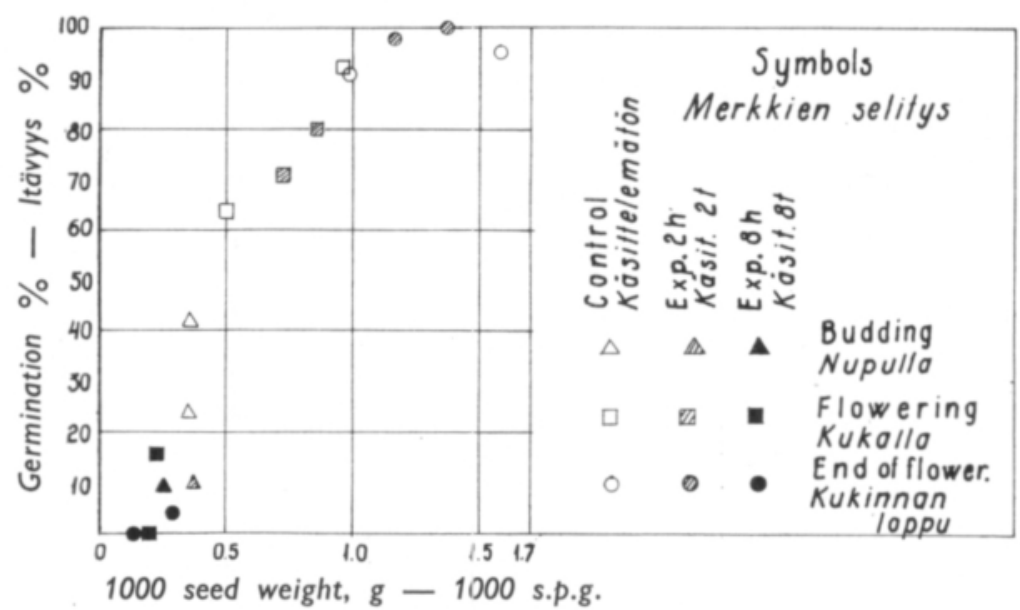

Fig. 6. Effect of the frost treatments ( 2 hours and 8 hours at $\left.-3^{\circ} \mathrm{C}\right)$ on heads at different stages of development. Treated 9. VIII, harvested 8. IX.

Kuva 6. Pakkaskäsittelyjen (2 ja 8 tuntia $\left.-3^{\circ} \mathrm{C}: s s a\right)$ vaikutus eri kehitysasteella oleviin mykeröihin. Käsitelty 9. VIII, korjattu 8. IX. 
B. The effect of frost at different stages of development

Since labelling of heads in different stages of development was done in the cold cabinet experiments as well as in the field, an idea can be obtained from the present material of the way in which the effect of frost depends on the degree of development or ripening of the head.

1. Cold cabinet experiments.

In Fig. 6 results obtained in the experiments in the cold cabinet have been presented. For details, see reference 11.

The present material is not extensive enough to enable any final statement to be made concerning the damage as a function of stage of development, temperature, and duration of the low temperature. It is obvious, however, that frost causes damage to the seed crop, not only by the death of stalks with their heads, but also by injuring the heads on the stalks that survive. According to the experiences that have been gained, such damage is observable, in part at least, a few days after the occurrence of frost. The heads have become darker in colour, but they differ from the heads darkened as a result of ripening in that they feel soft and seedless.

The phenomenon occurring with cereals that the seed crop injured by frost may be normal with regard to quantity and grain weight but has completely lost its germination ability was not observed in the cold cabinet experiments. No sample displayed a germinative ability lower than it might have been without frost, considering the seed size and the normal scattering of results.

Half of the material came from sufficiently limed soil and half from too acid soil. The clover grown on acid plots had distinctly suffered from acidity when compared to the stand of the limed plots. However, the liming had no decisive or statistically significant effect on the cold resistance of the clover heads and seeds. The data are, it is true, too scanty to show small differences in this respect.

\section{Natural frost.}

The effect of natural frosts on heads at different stages of development is most appropriately studied, at first, on the basis of the $\mathrm{mat}$ erial f r o m t h e y e a r 1960 . The "brown" stage of development had already then been divided into two, namely, "light brown" and "dark brown». The results can be seen in Fig. 7. Significant frost nights did not occur until late in the autumn. The occurrence of pollinators had ceased abruptly on 20. VIII, and although they reappeared later in some number, the fact that the heads flowering and budding on 30. VIII did not form any seeds can be due to the conditions of pollination.

The part (a) of Fig. 7 representing the harvesting time 25. VIII reveals that all ten samples with dark brown colour of the corollae on the day of harvesting and before the occurrence of frost had ripened so far that germination had reached its peak of $96-100 \%$ or had already begun to go down from this peak in the oldest individual plants. The "half-brown" heads (which had turned brown by one half but no more than $70 \%$ ), bore non-germinating or very poorly germinating seed. Even in the heads that had still to be counted as flowering, some quantity of extremely small ( $0.1 \mathrm{~g} 1000$ seed weight), non-germinating seed was found. 

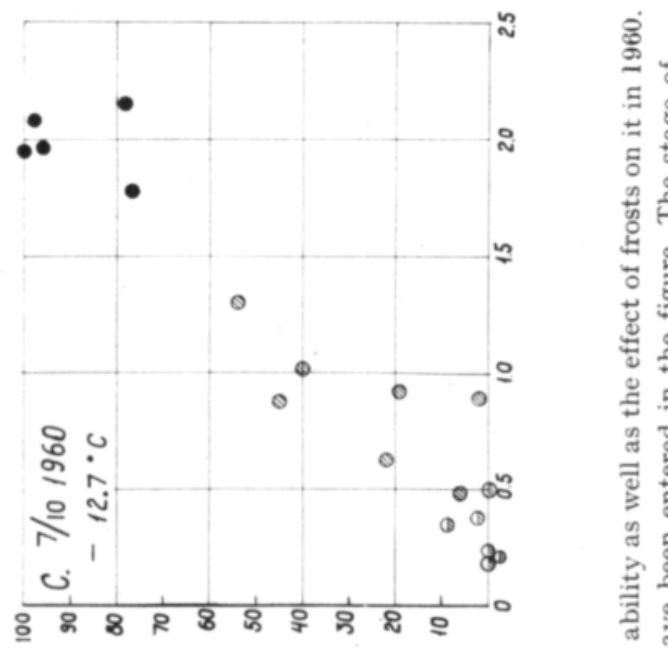

בี

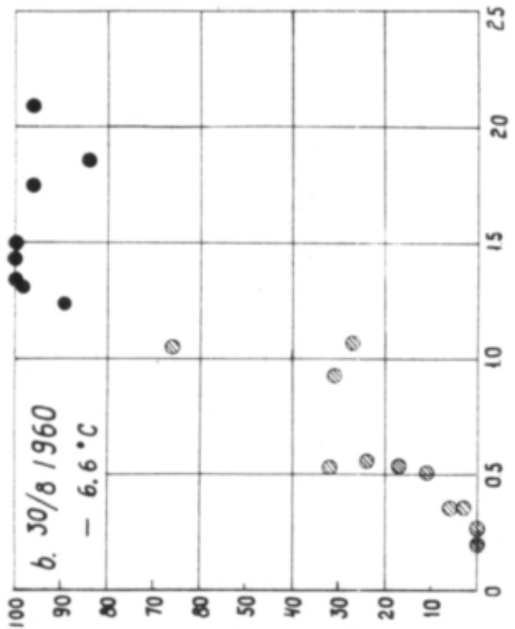

巳

栗

焉

on

主

สำ

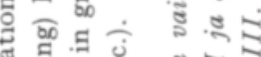

สำ ปี

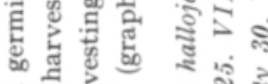

들 정

若造

충밍

承

욜

然

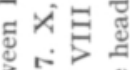

ฉ

ํํㄴ

ช้

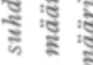

ฐ ญั ซี

ㅁํำ

总点

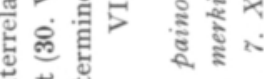

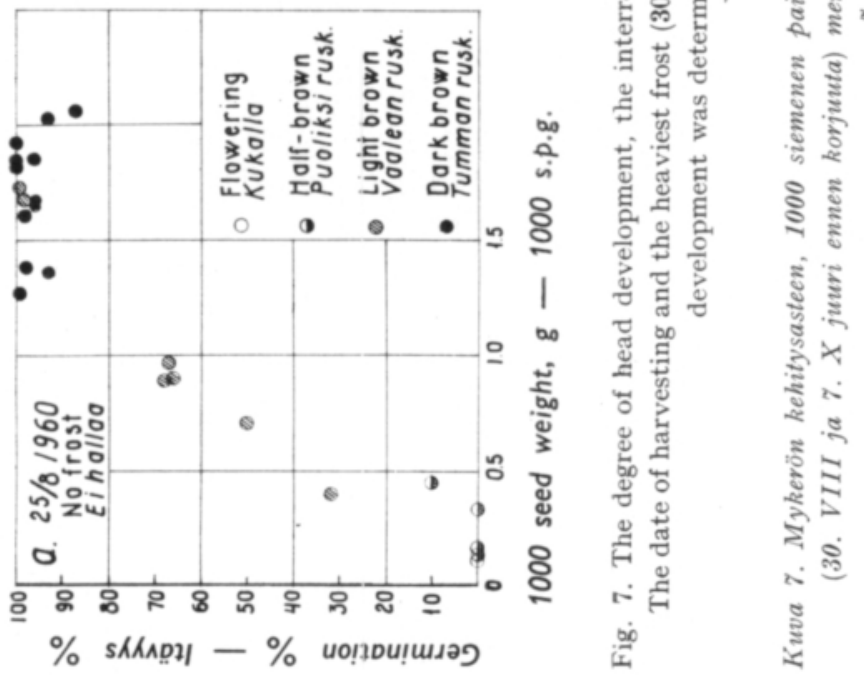


The stage of development at which more than $70 \%$ of the corollae are light brown constitutes an important intermediate phase. Three or four out of nine samples are equivalent to dark-brown heads in respect to size and germination ability of the seeds, while the others are more or less unripe. If the samples subjected to fairly slight frost $\left(-6.6^{\circ} \mathrm{C}\right)$ are taken into account $(30$. VIII), the variation in germinative ability of the light-brown samples covers the entire per cent range (accurately, the range from 0 to $99 \%$ ) and their 1000 seed weights vary $(0.20$ $1.73 \mathrm{~g}$ ) from the lower limit at which one begins to obtain seed by threshing methods employed in actual practice, and even lower values, to about the average weight of commercial seed. If this observation is generally valid, then the sorting of seed, insofar as it is done on the basis of the seed weight, mainly implies removal of seed that is in this particular stage of development. The distinction of this stage of ripening is thus justified, and it has also been done with comparative success in this case. The basis of determination employed in this work is easy and readily practicable in the field, although unfortunately the important upper limit (that between light and dark brown) is subjective and inaccurate and the material to which this subdivision has been applied is still rather limited.

According to Fig. $7 \mathrm{~b}$, the effect of a frost of $-6.6^{\circ} \mathrm{C}$ is fairly distinctly observable in the light-brown heads. In this figure the groups consisting of the lightbrown samples are clearly apart from the group of dark-brown heads in the series harvested both on 30 . VIII and on $7 . \mathrm{X}$, although the said groups partly overlap in the series not subjected to frost (25. VIII). The occurrence of such a nearly empty interval is not necessarily attributable to mere chance (although, of course, this possibility also has to be kept in mind in such a small series). Frost has such an abrupt effect, e.g. on the air-dry weight of the grain of spring cereals, that the weight is already lower on the day after the frost night than on the preceding day (6). A decrease of the 1000-seed-weight of this kind seems to have occurred also with clover in this series, particularly in the group of light-brown heads, in which the weight has gone down to about one half of its previous value as a result of the $-6.6^{\circ} \mathrm{C}$ frost. The average germinative ability has gone down from $74 \%$ to $20 \%$.

When germination figures are given, usually no intermediate forms between germinating and non-germinating seeds are stated. Such intermediate forms exist, namely, frost-injured shoots, which are counted among the non-germinating seeds, but according to the writers' experience their number is small in comparison with the unambiguous cases. This also holds true for cereals, the injured shoots of which are easier to observe than those of clover. Loss of germinative ability of an individual seed is thus a comparatively sudden and sharply demarcated phenomenon. Wellripened seeds tolerate frost quite well as a rule, also seeds of clover (according to the present investigation those borne in dark-brown heads). It is natural that the limit at which the seed barely tolerates a given frost effect coincides rather sharply with a given degree of ripening. If the effect exceeds this limit, the point plot made of a sufficiently homogeneous series may reveal a gap or rarefied portion of the kind as seen in Fig. 7 with the series harvested on 30. VIII and on 7 . X. That this gap happens to lie just between the pre-defined stages of ripening, "light brown" and 
"dark brown", which were marked in advance, merely indicates that the originally arbitrary choice of limit was a lucky and appropriate one.

In the heads which are half-brown and still flowering, no considerable lowering of germination percentage can occur because their germinative ability is low even initially. The principal injury is that the growth of the seeds comes to a stop. Thus, according to Fig. $7 \mathrm{~b}$-c, the seed in heads which were half brown on 30 . VIII was similar with respect to its size and germinative ability even as late as 7 . X, as the same seed might have been after the first serious frost, 38 days earlier. It seems that part of the seed in light-brown and dark-brown heads has been able to grow after a frost night with a temperature of $-6.6^{\circ} \mathrm{C}$. The germination percentages were about the same after the frost that occurred on $7 . \mathrm{X}\left(-12.7^{\circ} \mathrm{C}\right)$ as they were after that on 30 . VIII $\left(-6.6^{\circ} \mathrm{C}\right)$ except that the germination ability of the fully ripened seeds had perhaps begun to go down, possibly for other reasons rather than due to the frost. It is to be noted that the frosts of increasing strength have not caused any further decrease of germinative ability in the unripe seed; the condition rather seems to have remained the same as it was after the $-6.6^{\circ} \mathrm{C}$ frost of 30 . VIII, when obviously the major part of the unripe seeds ceased to grow.

Such marked heads which had been flowering, budding or about to bud on 30 . VIII were found in a total number of 16 on $7 . \mathrm{X}$, but they did not contain any seeds. The almost total disappearance of the pollinators on 25 . VIII is sufficient to explain the lack of seeds, but the appearence of the heads indicated that their development probably had stopped immediately or in a few days after the first frost night with $-6.6^{\circ} \mathrm{C}$ temperature.

In 1959 the stage of development of heads was marked in the field with the aid of coloured threads on 1. VIII, and the heads were harvested on different
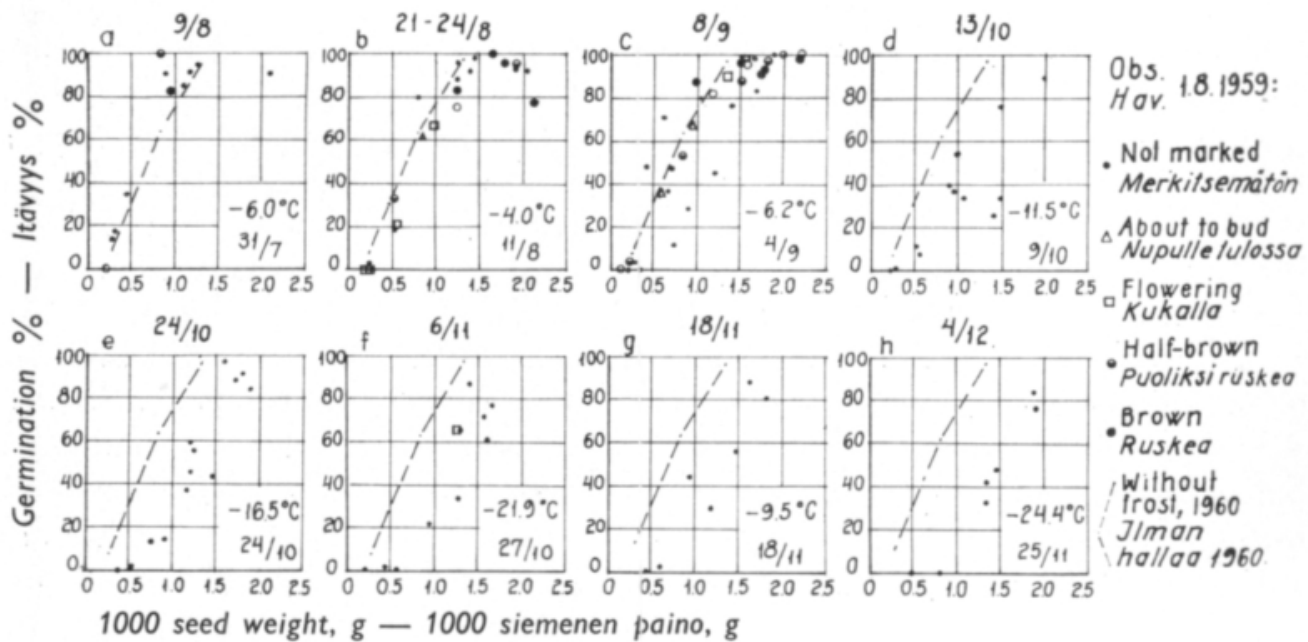

Half-brown

Puoliksiruskeo

Brown

Ruskea

Without

Irost, 1960

Jlman

hollog 1960

Fig. 8. Development of germinative ability under increasingly severe frosts in the autumn of 1959 . The heaviest frost that occurred after the preceding sampling has been entered on the graphs.

Kuva 8. Itävyyden kehitys syksyn 1959 kovenevissa pakkasissa. Edellisen näytteenottokerran jälkeen sattunut kovin pakkanen on merkitty piirroksiin. 
dates. The "light brown" and "dark brown" stages of ripening had not yet been separated in that year and they formed one common category of "brown". The results can be seen in Fig. 8. The broken line in the graph represents the normal relationship between seed size and germinative ability (without frost, 1960).

Immediately before the labelling of heads, a frost night with $-6.0^{\circ} \mathrm{C}$ occurred on 31 . VII, and before that there had been a night with $-5.0^{\circ} \mathrm{C}(17$. VII), without any visible injury having been caused to the heads by either. The major part of the labelled heads was harvested between 21 . VIII and 8 . IX, but some were taken already on 9. VIII and two were found as late as 6. XI. In Fig. 8 the results referring to unlabelled heads harvested at the same time have also been entered.

On the strength of the findings relating to labelled heads it is possible to conclude whether the growth of the seeds has continued after frost.

Ten heads which were just a b o t to bu d on the labelling date, 1. VIII, were found later, and six of them bore seeds. The absence of seeds in the other four may be due equally well to frost or to lack of pollination. The number of seeds in the seed-bearing heads was moderately high, 30 seeds per head and 61 seeds in the head that was most advanced in ripeness. These heads had thus tolerated a frost condition of $-6.0^{\circ} \mathrm{C}$ when about to bud; moreover one of them had undergone a frost of $-4.0^{\circ} \mathrm{C}$ and the others one of $-6.2^{\circ} \mathrm{C}$ prior to harvesting. Adjacent to the head the temperature may have been slightly higher, or also lower, than the said values, which were measured at plant top height, but the heads survived such dangerous conditions with normal germinative ability of their seed, considering the seed size. It is possible, however, that the development of the seed would have stopped at the size and germination ability that had been reached when the later frost occurred.

Among the heads that were $\mathrm{fully} \mathrm{bud} \mathrm{ding} \mathrm{on} 1$. VIII, both seedless heads, and heads with small seeds and heads bearing fully developed and germinating seeds were later found. On 8 . IX, four seedless heads and nine seed-bearing heads were harvested. The number of seeds per head was fairly low, in those with seeds the average was 21 seeds, but the seeds germinated normally, considering their size. Taking into account the small number of seeds and the dates on which frost occurred, the suspicion seems justified that the pollination has been rather poor. The heads harvested on 8 . IX had been subjected, at first, to $-6.0^{\circ} \mathrm{C}$ at the budding stage on 31. VII, and then when the seeds were still unripened or had just reached full size, at first to $-4.0^{\circ} \mathrm{C}$ on 11 . VIII and thereafter to $-6.2^{\circ} \mathrm{C}$ on 4 . IX. The seeds do not seem to have suffered from this.

Of the heads that were flowering on 1. VIII, as late as 8 . IX both seedless heads (two heads), heads with exceedingly small seeds (one head with 42 seeds, 1000 seed weight $0.15 \mathrm{~g}$ ) and heads containing smaller or larger seeds germinating at more than $80 \%$ (seven heads) still were found. The number of seeds was small as a rule. It can be noted that at least a considerable part of the heads still developed normal seed in spite of the $-6.0^{\circ} \mathrm{C}$ frost that occurred at the time of flowering. About the time of the frost that occurred 4. IX, this seed had already reached full size and had not suffered appreciably. It is likely, on the other hand, that in the one head with 42 quite small, non-germinating seeds the growth of the seed had ceased, owing to the frost that occurred at the time of flowering.

One of the heads which were $\mathrm{h}$ a $1 \mathrm{f}$ b row $\mathrm{n}$ on 1 . VIII when they were labelled, already bore fully germinable, though small $(0.8 \mathrm{~g})$ seed after eight days, as observed in a sample of four heads taken at random. The other three heads were seedless. The later analyses revealed widely variable sample batches, from seedless heads and heads containing very small and nearly non-germinating seeds, up to those with large seeds germinating at nearly $100 \%$. It is obvious that the frost of $-6.0^{\circ} \mathrm{C}$ on 31 . VII has stopped the growth of seeds in some of the then half-brown heads either immediately or within a short time. The series does not show whether the germination percentage had gone down at the same time from the height that had already been reached, but it has remained within the normal limits of variation. Part of the samples have continued their development and ripened without observable injury.

Of the 17 harvested heads which were $\mathrm{brown}$ at the time of labelling, 16 contained seeds, usually in normal number. It is possible that the frost had lowered the germinative ability in some 
heads, primarily in those that were light brown, but this lowering could have been by about 10 per cent units at the most. The injury appears less than that caused in 1960 by the frost of $-6.6^{\circ} \mathrm{C}$, but then the frost was also less severe not only in that the minimum temperature was $0.6^{\circ} \mathrm{C}$ higher but also because the temperature remained close to its minimum for a shorter time. There are no longer any labelled brown heads among the samples taken on 13. X and later, but it can be inferred from Fig. 8 that at least part of these heads still displayed good germination ability in their seeds as late as 24 . X, after a frost of $-16.5^{\circ} \mathrm{C}$, and that at least some heads had survived the gradually increasing frosts of early winter (ultimately $-24.4^{\circ} \mathrm{C}$ ), remaining attached to the stems, so well that no appreciable decrease of germination ability had occurred although the weather may have caused also other stress in addition to that implied by low temperature. It seems obvious that significant frost injury need not be feared any longer after the corollae of the heads have acquired a dark brown colour as a result of normal ripening.

S u m m a ri $\mathrm{z}$ in $g$ the observations concerning the significance of the plants' stage of development, the following observations can be made. Natural frost of about -6 to $-6.6^{\circ} \mathrm{C}$, which has destroyed only a few per cent of the vegetative parts of the clover plants and treatment in the cold cabinet at -3 to $-4^{\circ} \mathrm{C}$ during $2-8$ hours, which produced $5-50 \%$ frost injury of the vegetative parts, have affected the development of the seeds even in the heads which were not definitively destroyed at once. The series is too small to enable comparisons to be made in respect to the susceptibility to frost of budding, flowering and half-brown heads. It is quite possible that the injury has been greatest at the earliest stages, when the heads were budding or flowering, although this is not very clearly established, particularly for the reason that these observations were disturbed by the poor pollination in the late summer and in the autumn. In 1960 distinct lowering of germination percentage was observed as a result of $\mathrm{a}-6.6^{\circ} \mathrm{C}$ frost in those heads which had light-brown corollae when the frost occurred and in which the seed was not fully ripened (1000 seed weight between 0.4 and $1.3 \mathrm{~g}$ ). In 1959 the injury caused at the same stage by a frost of $-6.0^{\circ} \mathrm{C}$ was insignificant or nil; the minimum temperature of -6 to $-7^{\circ} \mathrm{C}$ at plant top height therefore seems to be the limit at which injury occurs in the field. Frost nights and the autumn cold no longer have any effect on the heads which have acquired a dark-brown colour as a result of ripening.

\section{Assessment of the likelihood of frost damage on the basis of seed size}

The very close correlation between the seed weight and the germination percentage of the seeds is not changed by slight frost even though injury might be caused to the seed. For instance, no change is observable in the cold cabinet experiments (Fig. 6) nor in what was recorded in 1959 after natural frost not exceeding $-6.0^{\circ} \mathrm{C}$ (Fig. 5 a). However, the series includes heads which were concluded in the foregoing to have suffreed from the frost, but it seems obvious that slight frost only stops the growth of the seeds, or delays it, without causing any loss of germinative ability.

In 1960 , when a frost of $-6.6^{\circ} \mathrm{C}$ struck an unhardened vegetation on 29 . VIII, the germination percentage of the fairly small seeds was lower at most by a few tens of per cent units from what the seed size would have implied. During the autumn and early winter of 1959 the germination ability of fairly small seeds was lowered 
as much as $40-50$ per cent units from what it must be considered to have been, but also other weather factors than frost alone may be involved. In this case, thus, the results indicate the effect which may have been produced mostly by the frost. This has to be taken into account in the way of a reservation when the information contained in Fig. 4 is considered.

In the series where no frost occurred, the curve representing the germination percentage as a function of the 1000 seed weight (Fig. 4) is convex upwards. The effect of a fairly strong frost night straightens the curve, as occurred in Fig. 5 b. In Fig. 8, likewise, transformation of the curve into a straight line or to a concave curve in the course of autumn and early winter can be seen; this is also clearly shown by Fig. 5 c, in which the material of 1960 has been included. Weather conditions thus exert a stronger effect (as expressed in per cent units) on smallish seeds than on large seeds (although it should be noted that no heads with very large seeds

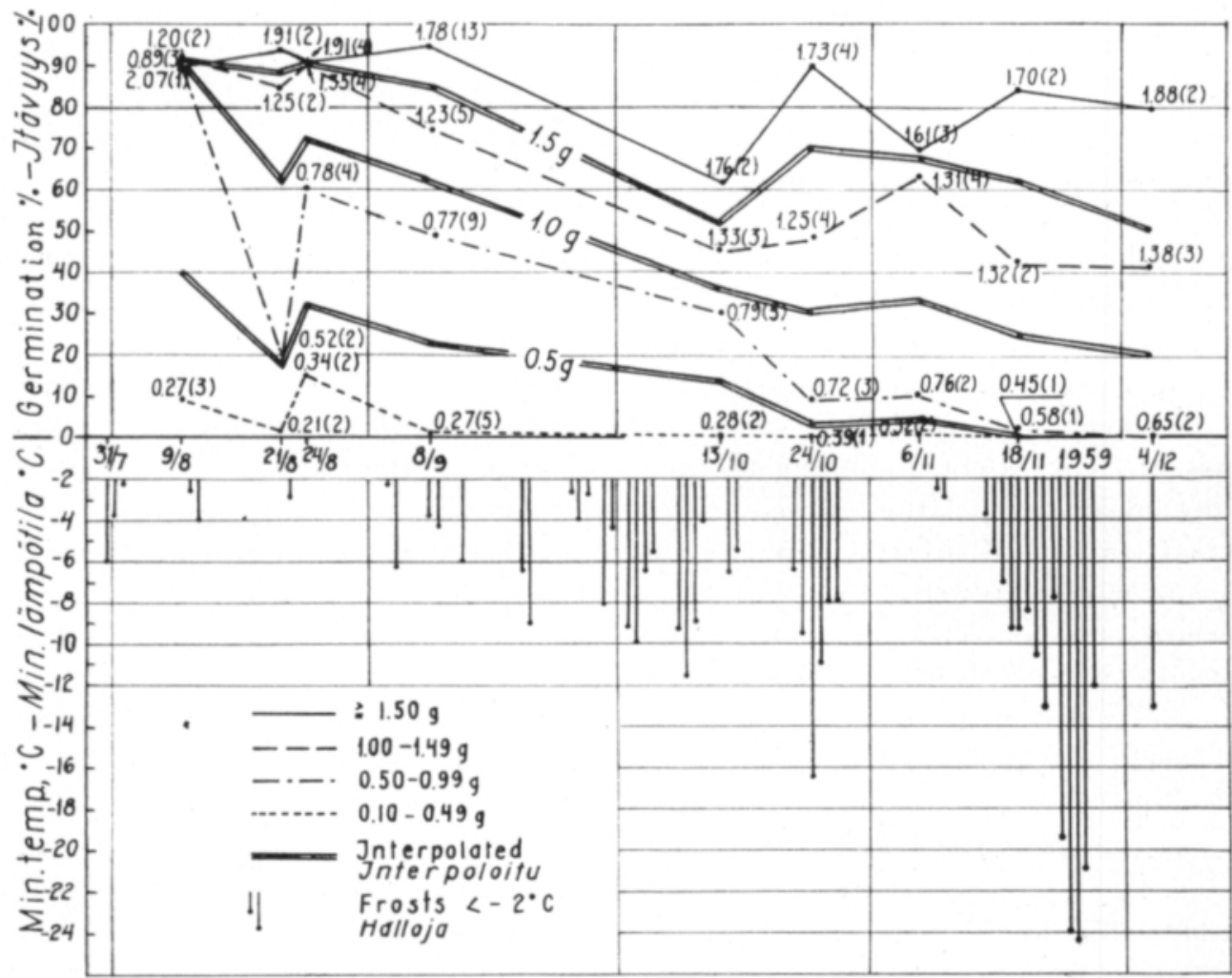

Fig. 9. The change of germinative ability of clover seeds belonging to different weight classes, and the night frosts during the period 9. VIII - 4. XII 1959. The first figure beside each dot is the 1000 seed weight in grams, the second (in brackets) the number of heads implied in each determination. The curves for the 1000 seed weight of $0.5,1.0$, and $1.5 \mathrm{~g}$ have been drawn on the basis of linear interpolation.

Kuva 9. Eri painolwokkiin kuuluvien apilan siementen itävyyden muuttuminen sekä hallat ajalla 9. VIII -4. XII 1959. Pisteiden vieressä oleva ensimmäinen luku on 1000 siemenen paino grammaa, toinen (sulkeissa) määritykseen sisältyvien mykeröiden lukumäärä. 1000 siemenen painoille $0.5,1.0$ ja $1.5 \mathrm{~g}$ on piirretty käyrät suoraviivaista interpolaatiota käyttäen. 


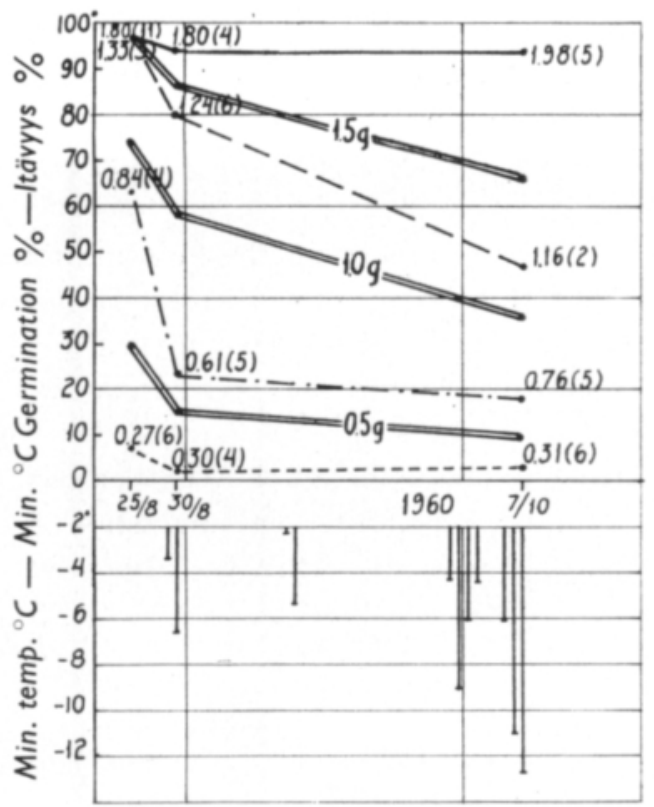

Fig. 10. The change of germination ability and the frost nights during the period 25. VIII 7. X. 1960. Symbols as in Fig. 9.

Kuva 10. Itävyyden muuttuminen ja hallat ajalla 25. VIII - 7. X 1960. Selitykset kuten kuvassa 9.

occurred in the latest analyses of 1959). In addition, the same tendency is observed in the smaller material of 1957 and 1958 (11).

Figs. 9 and 10 present the course of germination percentage in different seed weight classes in standing vegetation during the autumns 1959 and 1960, respectively. As the mean seed weight has varied appreciably even in one and the same weight class, the curves corresponding to $1.5,1.0$, and $0.5 \mathrm{~g} 1000$ seed weight are drawn using linear interpolation. Moreover, the interpolation smooths the curves to some extent. In both figures the topmost curve, corresponding to the weight class $1.5 \mathrm{~g}$ and over, indicates that the greatest seeds have tolerated quite well the gradually lowering temperatures down to $-24^{\circ} \mathrm{C}$ and the other effects of the weather in autumn and early winter. When the 1000 seed weight has been $1.5 \mathrm{~g}$ the germination percentage has gone down distinctly, about to the commercial limit percentage or even below. When the 1000 -seed-weight has been $1.0 \mathrm{~g}$ the germinative ability has been appreciably lowered already by normal harvesting time (the first days of September), and the lowering has still continued after that time. If seed of this size is left in the seed batch it may adversely affect the commercial value of the batch especially when the fact is taken into consideration that machine threshing and other treatments belonging to practical farming may lower the germination percentage from the level which has been reached in the hand-threshed experimental material.

Small seeds can be removed by sorting. It is possible by this means to improve considerably the commercial value of batches containing small seeds in general, but especially the value of a batch containing small seeds in great number as a result of frost. However, the inference is suggested by Figs. 5 and $8-10$ that it is advisible to harvest the seeds as soon as no further increase of the crop is to be expected. 
The scratching of the seed hull usually caused by machine threshing which diminishes the number of hard seeds has evidently been negligible in the present material. Hence this material allows one to study the effect of frost and autumn weather on the hardiness of the seeds.

Table 2. The amount of hard seeds as a percentage of the amount of germinating seeds (in parentheses the number of analyzed germinative seeds, and the number of corresponding test batches) in different classes of 1000 seed weight.

Taulukko 2. Kovien siementen määrä prosentteina itävien siementen määrästä (sulkeissa tutkittujen itävien siementen ja vastaavien idätyserien lukumäärä) 1000 siemenen painon mukaan jaoiteltuna.

\begin{tabular}{|c|c|c|c|c|c|}
\hline \multirow{2}{*}{$\begin{array}{l}\text { Years and } \\
\text { lowest } \\
\text { temperatures } \\
\text { Vuosi ja alin } \\
\text { lämpótila }\end{array}$} & \multirow{2}{*}{$\begin{array}{l}\text { Harvesting } \\
\text { time } \\
\text { Korjuu- } \\
\text { päivä }\end{array}$} & \multicolumn{4}{|c|}{$\begin{array}{l}\text { Percentage of hard seeds in different weight classes } \\
\text { Kovien siementen osuus eri painoluokissa }\end{array}$} \\
\hline & & $\geqq 1.50 \mathrm{~g}$ & $1.00-1.49 \mathrm{~g}$ & $0.50-0.99 \mathrm{~g}$ & $0.20-0.49$ \\
\hline \multicolumn{6}{|l|}{1960} \\
\hline \multicolumn{6}{|l|}{ No frosts - } \\
\hline Ei halloja & $25 / 8$ & $93(815,11)$ & $93(240,3)$ & $59(231,4)$ & $39(33,2)$ \\
\hline$-6.6^{\circ} \mathrm{C}$ & $30 / 8$ & $84(231,4)$ & $93(478,6)$ & $30(73,5)$ & $71(7,2)$ \\
\hline$-12.7^{\circ} \mathrm{C}$ & $7 / 10$ & $78(278,5)$ & $25(51,2)$ & $54(37,4)$ & $0(10,3)$ \\
\hline \multicolumn{6}{|l|}{1959} \\
\hline$-6.2^{\circ}$ & $9 / 8-8 / 9$ & $68(1344,20)$ & $63(782,13)$ & $53(500,18)$ & $28(46,6)$ \\
\hline$-16.5^{\circ} \mathrm{C}$ & $13-24 / 10$ & $62(360,6)$ & $36(272,8)$ & $20(170,8)$ & $0(1,1)$ \\
\hline$-24.4^{\circ} \mathrm{C}$ & $6 / 11-4 / 12$ & $62(240,7)$ & $47(335,9)$ & $17(23,2)$ & $0(1,1)$ \\
\hline
\end{tabular}

The data of the field samples are collected in table 2 . As the germinative ability is low in seeds which are small and harvested at late dates the material is scarce and the scattering large in these classes, but the main effects are rather distinct, however. For evaluating different statistical weights of the data the numbers of seeds and test batches are added to the table. Each test batch refers to one or several flower heads.

The percentage of hard seeds from the total number of germinative seeds varies from 93 to 0 per cent in Table 2 . It is highest in large, early harvested seeds which are saved from frost. In the weight class $1.5 \mathrm{~g}$ and over the effect of frost and autumn weather was rather small in both years. It is possible, however, that the numerous slight frosts which occurred in 1959 before the first harvest were the main cause for the fact that the percentage of hard seeds was smaller than in the next year. In the weight class $1.00-1.49 \mathrm{~g}$ and smaller the effect of the external conditions which are here characterized by minimum temperatures -12.7 to $-16.5^{\circ} \mathrm{C}$, has been appreciable in both years appearing in the "softening" of the seeds. In the lowest weight class the number of harvested germinable seeds has been very small but it 
is notable that no single hard seed has been found from the 12 germinable seeds and 5 test batches which have been subject to frost of $-12.7 \ldots-24.4^{\circ} \mathrm{C}$. The cold cabinet experiments and the preliminary tests in $1957-58$ contain only scanty information in this respect and do not alter the picture.

In 1959 no evidence is found that the seed could be softened during the last period, about one month, during which both thaw and strongly cold weather occurred. This observation, in addition, means that the frosts of -12.7 to $-16.5^{\circ} \mathrm{C}$ softened the hull of the seed more than the effect of weather conditions otherwise.

The influence of unfavourable weather may increase hard seeds in commercial material (1). In experiments the opposite effect has been noticed even earlier (8). The scratching of the seed hull by machine threshing, not the frost or any other direct effect of weather, may be the dominating factor causing variation in the percentage of hard seeds in the commercial red clover seed.

The effect of frosts in commercial clover seed, and the possibilities of seed production on frost-ridden farms

Although it has been found in the present work that frost may cause reduction of the germination percentage of clover seed from what is normal with seed of the same size, this decrease is far from equal in magnitude to that occurring in cereal grain, where nearly full-sized seed may entirely lose its germinative ability. It is therefore not easy for such damage to occur in clover which would not be noticed until the germinability determination was made. Seed that has been harvested in time and which is well-sorted and of normal size cannot be seriously frost-injured. Even if there might be frost-injured seeds in some number, their detection by defective shoots is more difficult than with cereals, according to the writers' experience. These circumstances already suffice to explain why frost damage is not revealed by the seed testing statistics and the accompanying reports. Also a couple of other factors may contribute to this effect. During a dry autumn there is a high risk of frost, but the injury caused to the seed by moisture is small; in wet autumns conditions are reversed, and the effects of climate thus cancel each other. Finally, it is also believed that clover seed cultivation is not practised in any considerable extent on farms susceptible to frost. On the strength of the present investigation, however, clover cultivation for seed production would be more appropriate for them than production of cereals.

There are difficulties connected with the cultivation of clover, and they are more numerous in seed production than in the production of fodder. According to the present investigation, frost risk does not add much to the difficulties in conditions such as the Frost Research Station represents, in which there is an appreciable risk in the cultivation of cereals and of potatoes. The analyses of clover heads reveal that pollination has also occurred with adequate efficiency during this work. It is possible that there would not be enough pollinators for extensive clover fields, but the individual clover seed fields are in fact small in the regions in question, and there is usually an abundance of willows, which are favourable for the multiplication 
of bumble-bees. It seems that cultivation of red clover for seed is suitable even for frost-ridden farms and it should be seriously considered when appropriate commercial plants are sought for such farms.

\section{$S u m m$ ar $y$}

The frost-resistance of Finnish red clover has been studied by means of experiments in a cold cabinet and on the basis of samples taken from the field.

In the cold cabinet experiments the frost injury of the clover plant's vegetative parts has reached considerable magnitude when the temperature was about $-4^{\circ} \mathrm{C}$. Also the unripe heads which did not die immediately could suffer so that the development of the seed stopped. Definitive death of the plants began to occur in the treatment at $-5^{\circ} \mathrm{C}$, though only when the soil was frozen. The plants recovered after treatment at $-10^{\circ} \mathrm{C}$ if the soil was not frozen.

In the field little frost injury of the vegetative parts occurred even with a frost of -6 to $-7^{\circ} \mathrm{C}$, but the unripe seeds suffered injury in that case. The germination percentage is distinctly dependent on the seed size in absence of frost. The stage of development at which more than $70 \%$ of the corollae are light brown constituted an intermediate phase where the variation in germinative ability was great and covered, when the samples subjected to slight natural frost $\left(-6.6^{\circ} \mathrm{C}\right)$ were taken into account, practically the entire per cent range $(0-99 \%)$. After the corollae of the heads had turned dark brown, at which time the seed had reached full weight, the seed suffered no injury from -6 to $-7^{\circ} \mathrm{C}$ frost, and even more severe frosts could at the most cause a very slight lowering of germination percentage.

Frost seems to injure the seed mainly by stopping the development of the unripe seeds. No lowering of germination from the level corresponding to the seed size has been observed in all cases nor was there any complete loss of germinative ability such as occurs with cereals. The commercial value of frost-injured red clover seed can be considerably increased by sorting.

The number of hard seeds is highest in large, early harvested seed. Frost evidently causes "softening" of germinative seeds.

The risk implied by frost is less in clover seed cultivation than in the cultivation of spring cereals and potatoes.

\section{REFERENCES}

(1) Ahlberg, E. 1965. Apilalajien kovien siementen itävyys. Koetoim. ja käyt. 22, 3: 5, 8.

(2) Jamalainen, E. A. 1958. Kasvien talvehtimisesta ja sen parantamismahdollisuuksista. Kasvinsuoj.seur. julk. 13. 39 p.

(3) Kamprinen, H. \& Schildt, R. 1965. Puna-apilan siementuotantomme. Kylvösiemen 1965, 1: 1335 .

(4) Kylvősiemen kasvintuotannon perustekijä. (Proclamation in world seed campaign by Agricultura. Society of Uusimaa and Association of Seed Producers of Uusimaa.) Kylvösiemen 1961, 1: 9-11. 
(5) PaAtela, J. 1959. Puna-apilan siementarve ja sen tyydyttäminen. Maatalous 52: $156-159$.

(6) Pessi, Y. \& Krvinen, P. 1957. Leikkuuajan vaikutuksesta ohran, kauran ja syysrukiin satoon sekä sadon käyttöarvosta kylvösiemenenä. Summary: On the influence of cutting time upon the crop yield of barley, oats and autumn sown rye and on the value in use of the grain crops as the seed. Publ. Finn. State Agric. Res. Board 161: 1-48.

(7) Rajala, K. 1958. Ohjeita apilan siemenviljelijöille. Maaviesti 1958, 1: 11-18.

(8) Schildt, R. 1958. Leikkuuajan vaikutuksesta puna-apilan siemensatoon. Koetoim. ja käyt. 15, 1: $2-3$.

(9) Umaerus, M. 1963. Chemical composition, flowering and morphological development of red clover under photoperiodic treatments and at different latitudes. Acta Agr. Scand. 13, 1: 17-64.

(10) VAlle, O. 1959. Kokemuksia teraploidista puna-apilasta Suomessa. Maatalous 52: 281-284.

(11) Valmari, A \& Valmari, I. 1965. Primary data of the paper »On the frost resistance of red clover with special attention to seed productions. 38 p. Pelsonsuo. (Stencil copies to be borrowed in the Library of the Agricultural Research Centre, Tikkurila, Finland, and available at Frost Research Station, Pelsonsuo, Finland.)

(12) YLIMÃKI, A. 1962. The effect of snow cover on temperature conditions in the soil and overwintering of field crops. Selostus: Lumipeitteen vaikutus maan lämpöoloihin ja peltokasviemme talvehtimiseen. Ann. Agric. Fenn. 1: 192-216.

\title{
SELOSTUS:
}

\section{PUNA-APILAN HALLANKESTÄVYYDESTÄ ERITYISESTI SIEMENEN TUOTANTOA AJATELLEN}

\author{
Arvi Valmari ja Irja Valmari
}

\section{Maatalouden tutkimuskeskus, Hallakoeasema, Pelsonsuo}

Suomalaisen puna-apilan hallankestävyyttä on tutkittu pakkaskaappikokeilla ja kentältä otettujen näytteiden perusteella.

Pakkaskaappikokeissa oli apilan vegetatiivisten osien paleltuminen huomattavan suuri n. $-4^{\circ} \mathrm{C}: \mathrm{n}$ lämpötilassa. Nekin tuleentumattomat mykeröt, jotka eivät heti kuolleet, saattoivat kärsiä tässä lämpötilassa siten, että siemenen kehitys pysähtyi. Osa kasveista kuoli lopullisesti $-5^{\circ} \mathrm{C}: \mathrm{n}$ käsittelyssä, jos maa oli jäätynyt. Ellei maa ollut jäätynyt, kasvit toipuivat vielä $-10^{\circ} \mathrm{C}: \mathrm{n}$ käsittelynkin jälkeen.

Kentällä oli vegetatiivisten osien paleltuminen $-6 \ldots-7^{\circ}$ :n hallassa vielä vähäistä, mutta tuleentumaton siemen kärsi jo vahinkoa. Mykerön kehityksessä se vaihe, jossa yli 70 \%:ssa kukista teriő oli muuttunut vaalean ruskeaksi, muodosti väliasteen, jossa siementen itävyyden vaihtelu oli suuri. Tässä kehitysvaiheessa itävyyden vaihtelu ulottuu tutkimusaineistossa melkein koko prosenttiasteikon alueelle $(0-99 \%)$, kun otetaan mukaan lievässä luonnon hallassa $\left(-6.6^{\circ} \mathrm{C}\right.$ kasvuston latvassa) mukana olleet näytteet. Sen jälkeen kun teriöt olivat muuttuneet tumman ruskeiksi, siementen saavutettua täyden painonsa, ei siemen ollut kärsinyt vahinkoa $-6 \ldots-7^{\circ}$ :n hallassa, ja enintään aivan pientä itävyyden alenemista saattoi aiheutua sitä kovemmista halloista.

Halla näyttää aiheuttavan apilan siemenelle vahinkoa etupäässä siten, että tuleentumattoman siemenen kehitys pysähtyy. Itävyyden alenemista siemenen kokoa vastaavasta tasosta ei kaikissa tapauksissa havaittu laisinkaan, eikä myöskään täydellistä itävyyden menetystä, jollaista esiintyy viljoilla. Lajittelulla voidaan hallan vioittaman siemenerän kauppa-arvoa parantaa huomattavasti.

Kovia siemeniä oli eniten suurikokoisessa varhain korjatussa siemenessä. Ilmeisesti halla vaikuttaa niin, että kovien siementen osuus itävien siementen yhteismäärässä pienenee.

Hallan vaara on apilan siemenen viljelyssä pienempi kuin kevätviljojen ja perunan viljelyssä. 